\section{Prospects for Higher Education in Latin America}

\section{Simon Schwartzman}

Simon Schwartzman is director of the Brazilian Foundation for Sustainable Development and the American Institutes for Research in Rio de Janiero, Brazil. E-mail: <simon@openlink.com.br>.

$\mathrm{I}$ $s$ it possible to speak of the prospects for higher education in Latin America, when the countries in the region are so diverse and their higher education systems so disparate? Enrollment rates (as of 1994) vary from 39 percent of the age cohort in Argentina, to 27 percent in Chile, about 14 percent in Mexico, and 11 percent in Brazil, Honduras, and Nicaragua. Private enrollments comprise 64 percent of the students in Colombia, 70 percent in El Salvador, and 58 percent in Brazil, in contrast to 6 percent in Uruguay, 20 percent in Argentina, and 25 percent in Mexico. ${ }^{1}$ The appearance of cultural homogeneity is also misleading. Peru, Bolivia, Paraguay, and Mexico have large native populations that speak their own languages, in contrast with Argentina and Uruguay, which do not. Brazil, Cuba, and the Dominican Republic have significant populations of people of African descent, and Haiti is a country of blacks who speak French.

Latin American higher education institutions also differ in various aspects. Some of the old Catholic universities in Spanish America were created in the 16th century, while the first universities in Brazil date from the 1930s. In some countries, private universities cater to the elite, while public universities are poorly supported and populated by students with few resources and with modest educational backgrounds. In others, public education is highly selective and of good quality, and poorer students have to look for places in low-cost, low-quality institutions, such as night schools.

What brings some consistency to all this is globalization. In the early 19th century, as the old Spanish and Portuguese empires crumbled and their colonies had to become modern states, universities were created to train military officers and lawyers who could build the new nations. The global model in those years was France, which exported to the new world the Napoleonic model of the centralized state and bureaucratically controlled institutions, together with the conflicts between church and state. In the 20th century, and more so after the Second World War, people flocked from the country to the cities, mass communications spread the attractions of consumption, and governments were called upon to provide the protection and services required by growing populations. For a while, it seemed that progress was everywhere, more rapidly and easily achieved in some places than in others, but all pointing in the same direction. At the turn of the millennium, however, the picture is more somber. It has been possible only for a minority - more in some places, less in othersto reach the necessary levels of income, education, and work to enjoy the benefits of modernization. For the majority, the aspirations are still there, more intense than ever, given the reach of the expanding mass media. However, the job market is shrinking, the cost of services-including health care and education-are rising continuously, and governments have exhausted their ability to provide services and meet the demands of their populations.

For the next century, one global trend we can expect is the movement toward the universalization of higher education. However, a common feature of higher education in the countries of Latin American-and elsewhere-is the inability of governments to keep responding to the demands. This is true for Argentina and Uruguay, which have reached European-like levels of student enrollment through public education, and for Brazil and Colombia, which kept their public systems small and allowed the private sector to supply most of the demand. In all cases, public higher education institutions will come under strong pressure to produce more, in quantity and quality, for the same amount or fewer resources; the private system, as it moves in to fill the gaps, will press for public subsidies and be questioned about the worthiness of its products and services.

\section{For the next century, one global trend we can expect is the movement foward the universalization of higher education.}

The pressure for reform, therefore, will fall upon both the public and the private sectors. First, there will be a growing demand for transparency. Evaluations, ranking systems, and accreditation boards, which are so common in Europe and the United States, have started to appear in Latin America and are likely to grow in importance. The main difficulty with these new yardsticks is that they threaten a long tradition of academic self-rule in Latin American universities. What they convey, in practice, is the notion that higher education is not something to be defined by academe but a matter of legitimate interest to others-those who pay the bill, those who need the services. This may seem obvious, but is not an easy transition to make.

While Latin American universities cherish their traditions of academic autonomy, they have always shunned administrative self-rule - taking responsibility for administering resources, establishing priorities, and making means and ends meet. These are things the private sector 
has always had to deal with, as will public universities now, if they are to become more efficient and cost-effective. The way most Latin American higher education institutions function-the absence of professional administrators, decisions taken by committees, and the strong presence and influence of labor unions, political parties, and movements-will have to be replaced or combined with a completely different managerial structure and style.

Yet the most difficult challenge for the next century has to do with content. Higher education institutions in Latin America, in the French tradition, were established to provide education and certification in the established professions of law, medicine, and engineering. The new institutions grew by creating mediocre versions of the traditional professional schools. The consequence was increasing frustration, as people found themselves with worthless degrees, while the traditional professions felt threatened by the growing and unqualified competition of the new institutions. In the 1960s and 1970s it was thought that the introduction of American-style graduate education and academic research would be the solution to this situation. As higher education continued to expand, the graduate and research programs of the 1960s and 1970s remained, at best, islands of quality and competence, without extending much beyond their establishments.

Now it is clear that institutional and content diversification is the only hope for the future. There will always be a place for professional education in the traditional mode, and for graduate education and research, but the main question is how to provide a meaningful content and work opportunity for the large majority of new entrants in such an unequal system. Latin American countries have little or no experience in providing technical, vocational, general, and continuous education to students, but it is likely that all these modes of postsecondary education will have to be developed as alternatives to traditional postsecondary progams.

A completely new environment for higher education may emerge in the region from these trends-with less state-sector and more private-sector education; wider use of evaluation and external assessment; introduction of new organizational structures and a more managerial culture; expansion of technical, vocational, and general education; and extending overall access. Some countries and institutions will respond better than others to these changes. Those that succeed will likely be better able to use another feature of globalization in the new century-that is, the easy access to information, communication, technical assistance, and exchange on a truly global scale.

\section{Note}

1. Carmen Garcia Guadilla, Situación y principales dinámicas de transformación de la educación superior en América Latina (Caracas, Venezuela: CRESALC/UNESCO, 1996).

\section{African Realities and Global Challenges: The $21^{\text {st }}$ Century}

\section{Jairam Reddy}

Jairam Reddy is a visiting scholar at the Center for International Higher Education at Boston College and at Michigan State University. He chaired the National Commission on Higher Education for South Africa.

$\mathrm{H}$ igher education systems have undergone profound changes during the latter part of this century. Elite systems of higher education have been superceded by mass and universal systems with a more diverse set of students. Central features of these changes are the demand for equity of access, declining state support, notions of accountability and quality, and responsiveness to socioeconomic imperatives. While African higher education has not been immune from these developments, political and economic realities have had grave consequences for its capacity to respond to change and to the needs of its populations.

The tradition of higher education in Africa is indeed a proud one-as exemplified by the universities at Al Azhar in Cairo, Kairouine in Fez, Debre Damo Axum in Ethiopia, and Sankore of Timbuktu in Mali. Fourah Bay College in Sierra Leone was established in Freetown in 1827. It was followed over a hundred years later by the University College of Gold Coast, Ghana in 1947, the University of Ibadan in 1948, University College of Addis Ababa in 1950, and others like Makerere in Uganda in 1946 and later universities throughout the continent. The number of universities increased from 20 in 1960 to 160 by 1996, while the number of students increased from 120,000 to over $2,000,000$ during the same period.

The undermining of democratic structures, their replacement by corrupt dictatorships, mismanagement of the economy, and perennial droughts have left a devastating trail of poverty and underdevelopment in much of the continent. Physical facilities in need of maintenance and refurbishment, the lack of technological infrastructure, and poor library resources are widespread features of current African higher education systems. Most devastating of all is the massive brain drain of skilled academic staff. The World Bank estimates that some 23,000 qualified academic staff are emigrating from Africa each year in search of better working conditions.

In South Africa, where material conditions for higher education have been considerably better, the ideology and practice of apartheid resulted in severe distortions of the higher education system: the participation rates of the 18to-21-year age cohort was over 70 percent for white students but less than 15 percent for black students.

How are African higher education systems to respond to the demands of their impoverished populations and the advent of globalization as we enter the new millennium? 